\title{
Formulation Development to Enhance the Residual Performance of Antimicrobial Agents on the Skin*
}

\author{
Takeshi Hisahara $^{* *}$, Keiji Kasahara ${ }^{* * *}$, Tadashi Shimada***, Hiroshi Matsui ${ }^{* * *}$ \\ Product Assurance Division **, Technical Development Center***, Mandom Corporation
}

Antimicrobial agents are used in deodorants to inhibit the growth of bacteria that transform sweat and sebum secretions into odorous compounds. In this study, we examined the ability of antimicrobial agents to enhance the deodorant effects. We first assessed changes over time in residual amounts of 4-isopropyl-3-methylphenol (IPMP) and 2,4,4'-trichloro-2'-hydroxydiphenyl ether (Triclosan) on axillary areas following the use of deodorants. The results suggested that the residual performance of Triclosan was significantly higher than that of IPMP. Second, in order to elucidate the causes of these reductions of the agents on axillary areas, we chose several factors and evaluated each contribution ratio. The results suggested that the primary factors were internal skin penetration and transition to clothes through sweat. Finally, we developed a screening method to evaluate the effects of the deodorant keeper that enhanced the residual performance of antimicrobial agents on the skin. The screening revealed that the deodorant keeper required certain characteristics: high molecular weight, high hydrophobicity and high affinity with antimicrobial agents. In the case of the deodorant keeper for IPMP, the polarized sites on the structure of the ingredients led to high affinity for IPMP because the dipolar interaction was enabled.

Key words : antimicrobial agent, deodorant, residual amount, 4-isopropyl 3-methylphenol (IPMP) , 2,4,4'-trichloro-2' -hydroxydiphenyl ether (Triclosan), penetration, transition, molecular weight, hydrophobicity, affinity, dipolar interaction

* Received, April 1, 2016; Accepted, July 7, 2016

**,*** 5-12, Juniken-cho, Chuo-ku, Osaka 540-8530, Japan

doi.org/10.5107/sccj. 51.33

(c) 2017 The Society of Cosmetic Chemists of Japan 


\title{
殺菌剤の肌上への残存性を高める処方技術の開発*
}

\section{久原丈司**, 笠原啓二***, 嶋田 格***, 松井 宏***}

株式会社マンダム 製品保証部**, 技術開発センター***

\begin{abstract}
デオドラント剤の防臭効果の持続性向上（ロングラスティング化）を目的として，臭いの原因とな る皮膚常在菌の繁殖を抑えるために, デオドラント剤に配合されている殺菌剤 4-イソプロピル-3-メ チルフェノール (IPMP) と2,4,4'-トリクロロ-2'-ヒドロキシジフェニルエーテル (トリクロサン) について、腋窝上での経時残存性を評価した結果, トリクロサンはIPMP よりも有意に経時残存性 が高いことが示唆された。次に, 殺菌剤の腋窩上での経時的な減少要因の解明として, 殺菌剤の揮発 性，皮膚内部への浸透性，皮膚表面での拡散性，衣服への移行性を評価した結果，皮膚内部への浸透 および衣服への移行が主要因であることが示唆された。また, 殺菌剤の腋窩での残存性を高める成分 （デオドラントキーパー）の探索を行った結果, デオドラントキーパーの要件としては, 皮膚内部へ の浸透を抑えるため分子量が大きいこと, 耐水性が高い必要があるためオクタノール/水 分配係数 （Log P） が大きいこと，殺菌剤との親和性（結合性）が高いことが必要であり, 今回評価した IPMP のデオドラントキーパーとしては, 分極部位を有しIPMP と水素結合等の双極子相互作用を 起こしやすい構造であることが, 残存性向上に有利に働くことが見出された。
\end{abstract}

\section{1. 緒}

\section{言}

われわれは，皮膚や毛髪上に製剂を塗布した後に残存す る微量成分を精度よく測定し, 効果性・持続性・機能性の 向上を裏付ける技術・メカニズムを実証することで, 生活 者満足度の高い化粧品・医薬部外品の開発に繋げている。

弊社の調査に扔いて, デオドラント剤に対する生活者の 要望の上位に, デオドラント効果の持続性の向上が挙げら れている。デオドラント効果の持続性向上を目指す方法と しては，臭いの原因となる皮膚常在菌 ${ }^{11,2)}$ の繁殖を抑える 目的で配合されている有効成分（殺菌剂）の皮膚残存性を 向上させる技術が考えられる。

そこで，殺菌剤として IPMP $^{3}$ (Fig.-1) およびトリクロ サン4) (Fig.-2）の 2 種を選定し，デオドラント剤使用後の 腋窩上での殺菌剤の経時的な減少挙動の把握を行った。ま た，減少要因を解明するため, IPMP 拧よびトリクロサン の揮発性, 皮膚内部一の浸透性, 皮膚表面上の拡散性, 衣 服への移行性を評価し, 減少の主要因についての解析を 行った。さらに, 本解析により得られた知見をもとに, 殺 菌剂の流れ落ちにくさを評価するスクリーニング系を作製 し，製剤中に添加することで殺菌剂の腋窩上での残存性を

\footnotetext{
* 2016.4.1 受付, 2016.7.7 採用
}

**,*** $\bar{\top} 540-8530$ 大阪市中央区十二軒町 5-12
高める成分（通称デオドラントキーパー）の探索を行った。 本報では，以上の具体的な結果を示し，腋窩上での残存 性の高い殺菌剂抢よびデオドラントキーパーとして有効な 添加成分の構造などについて考察する。

\section{2. 実験}

\section{1. 殺菌剤の残存性の評価}

$0.1 \%$ IPMP およよ゙ $0.1 \%$ トリクロサンを含む $70 \%$ エ夕 ノール溶液約 $0.2 \mathrm{~g}$ を 6 人の被験者の腋窩に塗布し, 塗布 前後の重量から塗布量を算出した。塗布直後, 塗布から 0.5 時間, 1 時間㧍よび 3 時間経過後に, エ夕ノールを含 浸させた不織布で腋窩を拭き取り,さらに 2 回同様に拭き 取り, 計 3 枚の不織布をメタノールで抽出し, 評価検体と した。この検体中の IPMP およびトリクロサンを高速液体 クロマトグラフィー（HPLC）で定量し，各時点での腋窩 上の殺菌剤の残存量を求めた。また, 残存量を検体塗布量 で補正し，0 時間後からの残存量の変化を残存率（\%）と して算出した。以下にHPLCの条件を示す。 IPMP 分析条件

カラム : Shiseido CAPCELL PAK C18 UG120 $(4.6 \times 150 \mathrm{~mm}$, 粒子径 : $5 \mu \mathrm{m})$

カラム温度 : $40^{\circ} \mathrm{C}$

移動相：60\%メタノール溶液

流 速 : $1.0 \mathrm{~mL} / \mathrm{min}$ 


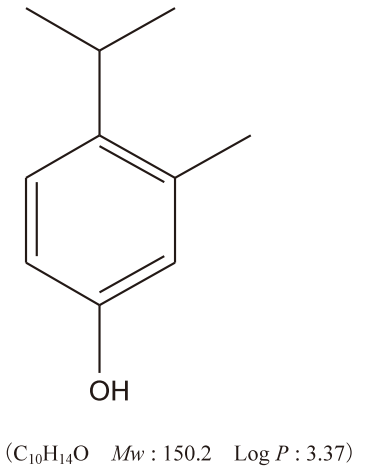

Fig.-1 Chemical structure of 4-isopropyl-3-methylphenol (IPMP).

注入量 : $20 \mu \mathrm{L}$

検出器: 島津製作所社製 蛍光検出器 RF-10A $A_{x L}$

検出波長 : Ex : $292 \mathrm{~nm}, E m: 308 \mathrm{~nm}$

トリクロサン分析条件

カラム：Shiseido CAPCELL PAK C18 UG120

$(2.0 \times 150 \mathrm{~mm}$, 粒子径 : $3 \mu \mathrm{m})$

カラム温度 : $40^{\circ} \mathrm{C}$

移動相：アセトニトリル $/ 5 \mathrm{mM}$ ギ酸アンモニウム溶液

$(3: 2)$

流 速: $0.3 \mathrm{~mL} / \mathrm{min}$

注入量 : $20 \mu \mathrm{L}$

検出器: AB SCIEX 社製 LC/MS/MS API 2000 ${ }^{\mathrm{TM}}$

イオン化法：ESI negative

定量イオン: 287

\section{2. 減少要因の解析}

\subsection{1. 殺菌剤の揮発性の評価}

褐色バイアルにJIS 染色堅ろう度試験用ケラチン布（ケ ラチン布）（2 cm 四方）を敷き， $0.1 \%$ IPMP および $0.1 \%$ トリクロサンを含む $70 \%$ エタノール溶液を $1 \mathrm{~mL}$ 含浸さ せ， $30 ， 35,40^{\circ} \mathrm{C}$ で1時間インキュベート後, 褐色バイア ル中に残存している殺菌剤を定量し，残存率（\%）を算出 した。

\subsection{2. 殺菌剤の浸透性の評価}

$1 \%$ IPMP および $1 \%$ トリクロサン含有 $70 \%$ エタノール 溶液を前腕内側部に $2 \mu \mathrm{L}$ 塗布し（塗布径 $1 \sim 2 \mathrm{~mm}$ ), 塗 布後 10 分または 60 分後に 15 枚テープストリッピングを 行い（テープ径 $20 \mathrm{~mm}$ ), テープに付着している殺菌剂を メタノールで抽出, HPLCで定量し, 回収率（\%）を算出 した。

\subsection{3. 殺菌剤の拡散性および移行性の評価}

自社デオドラントロールオン $(0.1 \%$ IPMP, $0.2 \%$ トリク ロサン含有）約 $0.2 \mathrm{~g}$ を腋窩に塗布し， 6 時間後に腋窩を

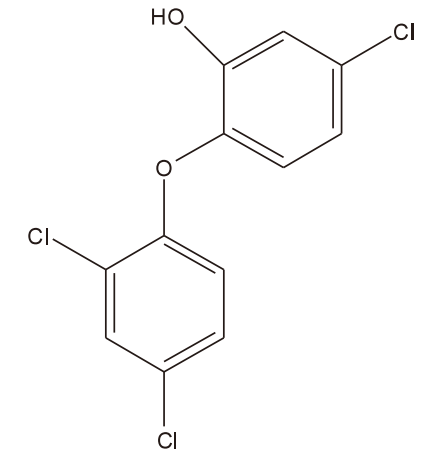

$\left(\mathrm{C}_{12} \mathrm{H}_{7} \mathrm{Cl}_{3} \mathrm{O}_{2} \quad M w: 289.5 \quad \log P: 4.86\right)$

Fig.-2 Chemical structure of 5-chloro-2-(2,4-dichlorophenoxy) phenol (Triclosan).

拭き取り，回収された殺菌剤を定量することで残存率 (\%) を, 首から下の上半身を拭き取り, 回収された殺菌剂を定 量することで拡散率（\%）を，着用していた衣服（Tシャ ツ）をメタノールで抽出・定量することで衣服への移行率 （\%）を算出した。

\subsection{4. 残存性に及ぼす発汗の影響}

$0.1 \%$ IPMP 拉よび $0.1 \%$ トリロサン含有 $70 \%$ エタノー 儿溶液約 $0.2 \mathrm{~g}$ を腋窩に塗布し， $27^{\circ} \mathrm{C}, 65 \% \mathrm{RH}$ 条件下で 30 分間デスクワーク後（通常時）の腋窩上の殺菌剤の残 存率（\%）と，検体塗布後に $33^{\circ} \mathrm{C}, 50 \% \mathrm{RH}$ 条件下でサ イクルエルゴメーターによる運動負荷試験を 15 分間行 い,ささらに 15 分経過後（発汗時）の腋窩上の殺菌剤の残 存率（\%）を比較することで，殺菌剤の残存性に及ぼす発 汗の影響を評価した。

\section{3. デオドラントキーパーの探索}

\subsection{1. 評価成分}

DPA: diisopropyl adipate, DBA: diisobutyl adipate, IM: isopropyl myristate, INI: isononyl isononate, IP: isopropyl palmitate, EP: 2-ethylhexyl palmitate, ES: 2-ethylhexyl stearate, SSI: sorbitane sesquiisostearate, GE: glyceryl tri 2-ethylhexanoate, OM: 2-octyldodecyl myristate, PE: pentaerythritol tetra 2-ethylhexanoate

\subsection{2. 試料溶液の調製}

$0.1 \%$ IPMP, $1 \%$ ポリオキシエチレンポリオキシプロピ レンデシルテトラデシルエーテルを含む $70 \%$ エタノール 溶液をベース処方とし，上記の評価成分を $1 \%$ 添加したも のを試料溶液とした。また, ベース処方をコントロール溶 液とした。

\subsection{3. 残存性の評価法}

ケラチン布（3 cm 四方）4枚にマイクロピペットを用い て試料溶液を $20 \mu \mathrm{L}$ 塗布し, 10 分間静置後, 3 枚の塗布 面を下にして酸性人工汗液（JIS L0848：2004）に浮か心゙, 
$100 \mathrm{rpm}$ で 10 分間振とうを行った。その後, 4 枚のケラチ ン布に残存したIPMPをメタノールで抽出し, HPLCでの 定量を行った。各試料溶液での IPMP の残存率 $(a \%)$ は, 人工汗に浮かべた 3 枚のケラチン布の IPMP 残存量の平均 值を，人工汗に浮かべなかった残り 1 枚のケラチン布の IPMP 量で割ることにより求めた。また，コントロール溶 液を同様に操作して残存率 $(b \%)$ を求め, 評価成分添加 による殺菌剤残存量の上昇率 $(x \%)$ を $x=a / b \times 100-100$ により求めた。

\subsection{4. 回帰式の算出}

デオドラントキーパーの効果性を予測するための回帰式

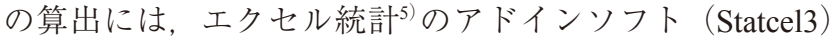
を用い, $F$ 值が 2 以上ならば有効な説明変数とした変数増 加法による重回帰分析を行った。また, 説明変数として

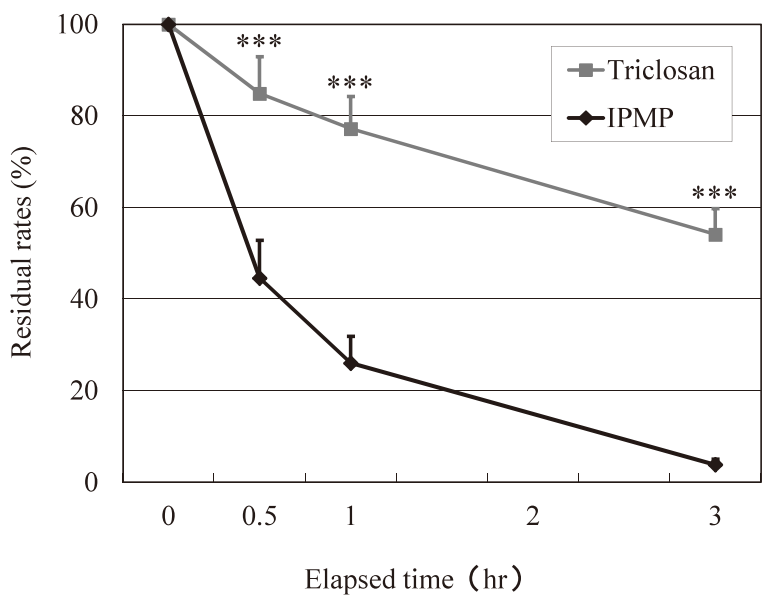

Fig.-3 Comparison of the residual rates on axillary areas between Triclosan and IPMP after sample application.

Mean $+\operatorname{SD}(n=6) .{ }^{* * *}: p<0.001$ (paired $t$ test).

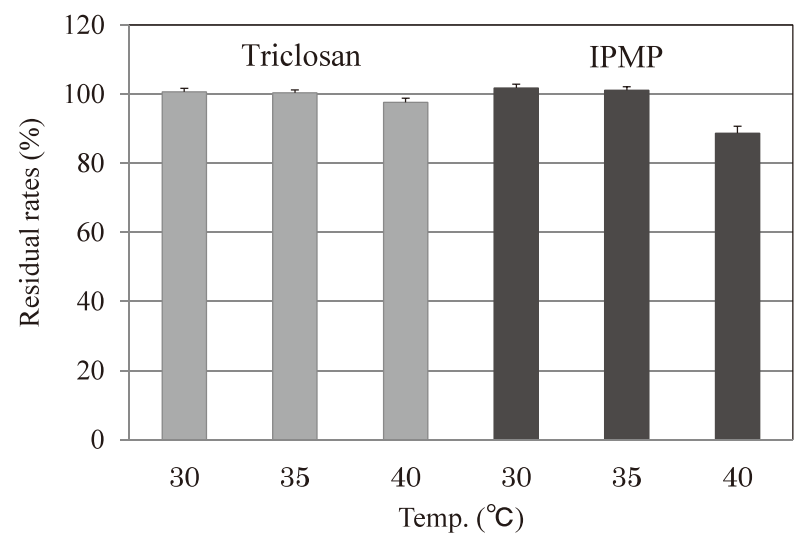

Fig.-4 Evaluation for volatility of Triclosan and IPMP. Mean $+\operatorname{SD}(n=3)$.
は, 数值データが入手可能であった分子量, $\log P$, 沸点, モル体積, モル屈折率, 分極率, 表面張力, 水溶解度 $(\log S)$, 有機性值 $\left.{ }^{6}\right)$, 無機性值 $\left.{ }^{6}\right)$ の 10 種類のパラメータを 用いた。

\section{3. 結果}

\subsection{IPMP, トリクロサンの経時残存性の比較}

$0.1 \%$ IPMP および $0.1 \%$ トリクロサン含有エタノール溶 液を 6 名の被験者の腋窩に塗布し，30 分後， 1 時間後， 3 時間後に腋窩上に残存している殺菌剤を回収し，残存率を 求めた結果を Fig. -3 に示す。本試験結果において，腋窩 上に塗布されたIPMP およびトリクロサンは経時的に減少 し，特にIPMPは 3 時間後には $10 \%$ 以下の残存率であっ た。また, 経時 30 分以降の IPMP の残存率はトリクロサ ンに比べて有意に低いという結果であった。

\section{2. 殺菌浏の減少要因の解明}

Fig.-3にみられた殺菌剂の経時的な減少要因の解明とし て，要因を(1)揮発，(2)皮膚内部への浸透，(3)皮膚表面での 拡散，(4)衣服への移行に分類し，各要因について 2 種の殺 菌剤を用いた以下の評価を行った。また，殺菌剤の減少挙 動に与える発汗の影響も検証した。
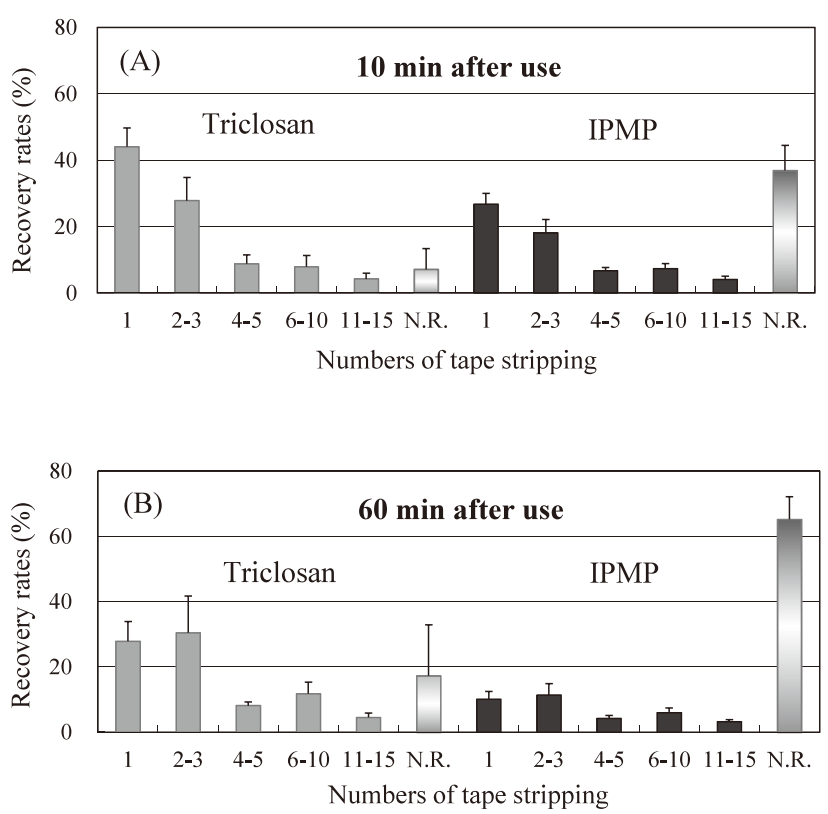

Fig.-5 Evaluation for permeability to the skin by a tape stripping method.

The numbers below the bars indicate the number of times of stripping, and the bars indicate the recovery rates of Triclosan and IPMP from the tape. (A) $10 \mathrm{~min}$ after use, (B) 60 min after use, Mean $+\operatorname{SD}(n=3)$. 


\subsection{1. 揮発性の評価}

殺菌剂の揮発性の評価として, $30^{\circ} \mathrm{C}, 35^{\circ} \mathrm{C}, 40^{\circ} \mathrm{C}$ で 1 時 間インキュベートしたときのIPMP およびトリクロサンの 残存率を評価した結果を Fig. -4 に示す。本試験条件にお いて，トリクロサンの減少はほとんどみられず，IPMPは $40{ }^{\circ} \mathrm{C}$ 条件下でのみ $10 \%$ 程度の減少がみられた。

\subsection{2. 皮膚内部への浸透性の評価}

殺菌剤の皮膚内部への浸透性の評価として，検体を前腕 内側部に塗布したのちテープストリッピングを行い, 皮膚 内部の殺菌剤を回収することで浸透性を評価した結果を Fig. -5 および Table-1 に示す。本試験条件において, 塗布 10 分後に比べて 60 分後の殺菌剤の回収率は低下し, 未回 収率が増加した。また, 15 回のテープストリッピングに より回収された 2 種の殺菌剤の総量は, 塗布 60 分後では トリクロサンは $82 \%$ であったが, IPMPは34\%であり, 66\%が未回収であった。なお，ストリッピング部位以外の 前腕をエタノール含浸不織布で拭き取ったが, ほとんど殺 菌剤は回収されず（1\%以下）, IPMP は皮膚の表面温度（約 $\left.33^{\circ} \mathrm{C}\right)$ ではほとんど揮発しないことが Fig. -4 で確認され ているため, 未回収の要因は, 15 回のテープストリッピ ングにより回収された角層よりもさらに内部へ浸透したた めと考えられた。

\subsection{3. 皮膚表面での拡散性および衣服への移行性の 評価}

皮膚表面での拡散性および衣服への移行性の評価とし
て, 検体塗布 6 時間後の腋窩, 腋窩以外の首から下の上半 身および着用していた衣服（Tシャツ）に存在する殺菌剂 の定量を行った結果を Table-2 に示す。本試験条件におい て, IPMP は腋窩および夜窩以外の体表からは約 4\%しか 回収されず，約 $96 \%$ が肌上から消失しており，最も多く （53\%）の IPMP が回収されたのは衣服からであった。ま た，約 $43 \%$ が未回収であったが，3.2.2の知見をもとに， 浸透による消失であると推定された。同様にトリクロサン についても，衣服から $40 \%$ と最も多く回収され，浸透に よると推定される消失が $26 \%$ みれた。

\subsection{4. 発汗の影響}

3.2 .3 より殺菌剂の減少の主要因が衣服への移行である ことが示唆されたため, 移行に関与すると予想される発汗 の影響を評価することを目的に，通常時と発汗時の殺菌剂 の残存率を比較した結果を Fig. -6 に示す。本結果より, 発汗時の殺菌剤残存量は通常時に比べて有意に低く, 発汗 により肌上の殺菌剤の減少が加速することが確認された。

\section{3. 殺菌剤の残存性を高める添加成分の探索}

\subsection{1. 評価法の作成}

これまでの結果より, 殺菌剤の減少の主要因が衣服への 移行であり，その移行には汗が影響しているという知見が 得られたため，汗による流れ落ちを模したin vitro 評価法 を作成し, 自社デオドラント 3 剂型（ロールオン，クリー ム，スティック）を用いて IPMPの残存性を評価した結 果, in vivo での評価結果と同様の傾向 (ロールオン<クリー

Table-1 Evaluation for permeability to the skin by a tape stripping method. The description of "Recovery rates of 1-3" means the total recovery rates of antimicrobial agents from the tapes stripped to 1-3 times.

\begin{tabular}{lcccc}
\hline & $\begin{array}{c}\text { Elapsed time } \\
\text { after use }\end{array}$ & $\begin{array}{c}\text { Recovery rates } \\
\text { of } 1-3\end{array}$ & $\begin{array}{c}\text { Recovery rates } \\
\text { of 4-15 }\end{array}$ & No recovery \\
\hline Triclosan & $10 \mathrm{~min}$ & $72 \%$ & $21 \%$ & $7 \%$ \\
\multirow{3}{*}{ IPMP } & $60 \mathrm{~min}$ & $58 \%$ & $24 \%$ & $18 \%$ \\
& $10 \mathrm{~min}$ & $45 \%$ & $18 \%$ & $37 \%$ \\
& $60 \mathrm{~min}$ & $21 \%$ & $13 \%$ & $66 \%$ \\
\hline
\end{tabular}

Mean, $n=3$.

Table-2 Evaluation for recovery rates of Triclosan and IPMP from each of the parts at $6 \mathrm{~h}$ after use.

\begin{tabular}{lcccc}
\hline & \multicolumn{4}{c}{ Recovery rates (\%) } \\
\hline $\begin{array}{l}\text { Recovery } \\
\text { areas }\end{array}$ & Axilla & $\begin{array}{c}\text { Skin surface } \\
\text { except axilla }\end{array}$ & Clothes & No recovery \\
\hline Triclosan & $30 \%$ & $4 \%$ & $40 \%$ & $26 \%$ \\
IPMP & $3 \%$ & $1 \%$ & $53 \%$ & $43 \%$ \\
\hline
\end{tabular}

Mean, $n=3$. 


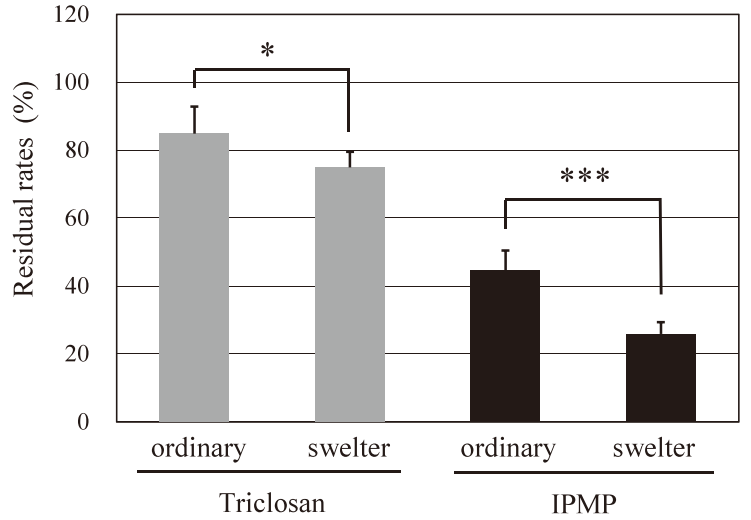

Fig.-6 Evaluation for effects of sweating on the residual rates of Triclosan and IPMP.

Mean + SD $(n=8){ }^{* * *}: p<0.001,{ }^{*}: p<0.05$ (Student's $t$-test).

ムくスティック）であったことから，本評価法の妥当性を 確認した（data not shown）。

\subsection{2. デオドラントキーパーの効果性の評価}

殺菌剂を肌上に留める成分, 通称デオドラントキーパー の探索を目的とし, Table-3に示す 11 種類の成分につい て, IPMP の残存量に与える影響を評価した結果を Fig.-7 に示す。本結果では評価した 11 検体すべてにおいて, IPMP の残存量の上昇が認められた。また，IM と IP, GE と PE どの類似構造化合物での比較において, 分子量お よび $\log P$ が大きいほど残存量が上昇する傾向がみられ た。

\subsection{3. デオドラントキーパーの解析}

デオドラントキーパーとしての要件を明らかにするた め, 3.3.2 の結果をもとに重回帰分析を用いて IPMP 残存 量の上昇率の予測式を求めたところ，下記に示す式におい て最も高い相関係数が得られた（Fig.-8）。

IPMP 残存量の上昇率の予測值 $(\%)=$

$M w \times 0.123+\log P \times 5.50$ - 有機性值 $\times 0.152$

+ 無機性値 $\times 0.107-18.2$

$$
(R=0.884, \quad p<0.05)
$$

本結果より，IPMP に対するデオドラントキーパーとし ては, 分子量, $\log P$, 無機性值が高いほど効果が高く, 有機性值はマイナスに影響することが示唆された。

\section{4. 考察}

\section{1. 殺菌剤の肌上での挙動について}

IPMP 㧤よびトリクロサンの腋窩上での減少挙動を評価 した結果, 特にIPMP は経時的に顕著に減少することが示

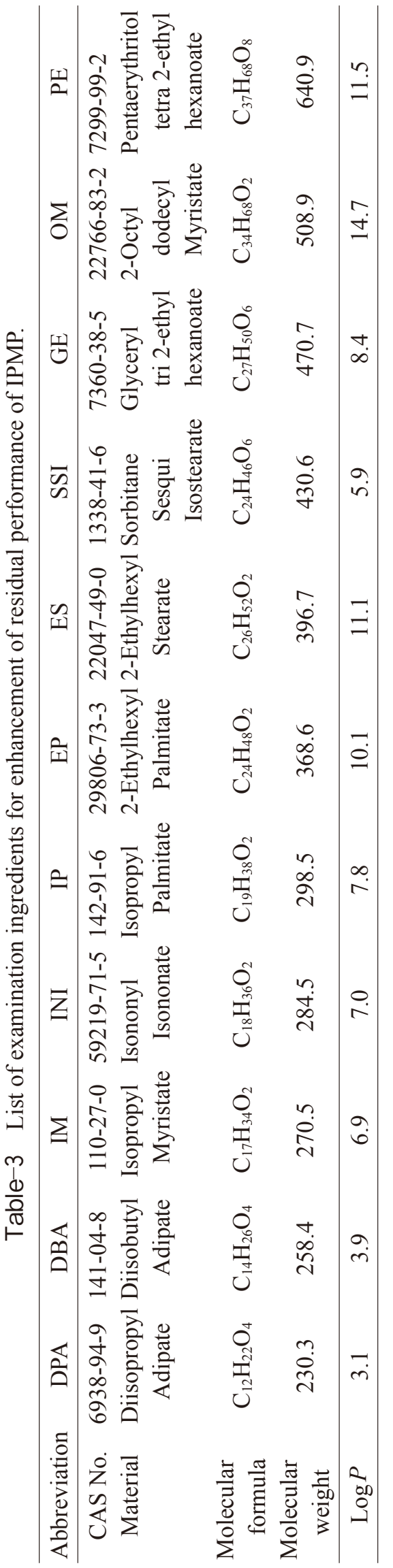




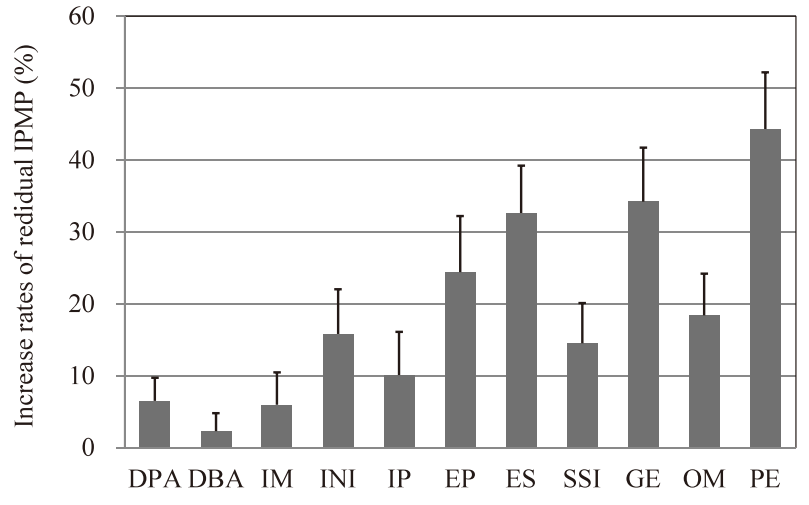

Fig.-7 Evaluation for the effects of additional ingredients on the enhancement of the residual performance of IPMP.

Mean + SD $(n=3)$.

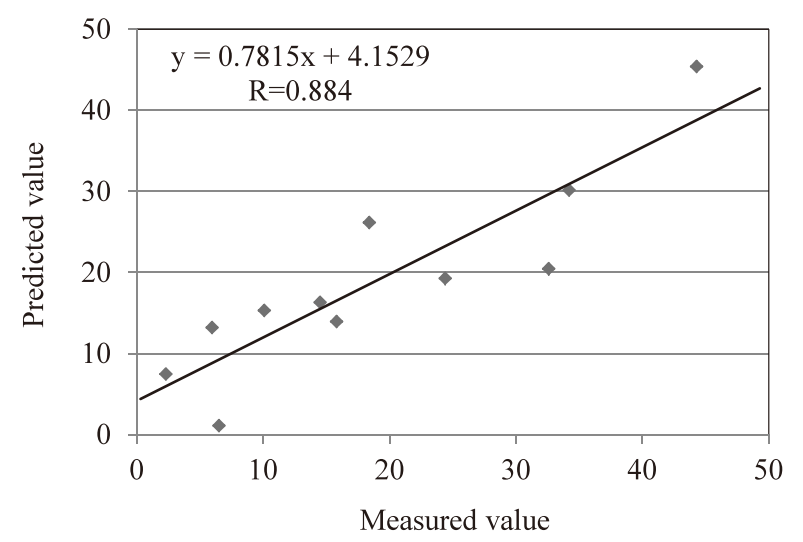

Fig.-8 Correlation diagram between measured and predicted values by multiple regression analysis for effects of additional ingredients on enhancement of residual performance of IPMP.

唆され（3.1），このことがデオドラント効果の持続性を損 ねる要因であると考えられた。

この減少要因を(1)揮発，(2)皮膚内部への浸透，(3)皮膚表 面での拡散, (4)衣服への移行に分解し，それぞれ評価を 行った結果, (1)揮発による減少は, 上腕内側部の表層温度 (約 $33^{\circ} \mathrm{C}$ ) 付近では, IPMP, トリクロサン共にほとんど 起こらないことが確認された（3.2.1）。また, (2)皮膚内部 への浸透は，前腕内側部を用いたテープストリッピングに よる評価により，特にIPMPにおいて顕著に起こり得るこ とが示唆された（3.2.2）。さらに，3.2.3において塗布 6 時 間後の体表からは殺菌剤はほとんど回収されず，特に IPMP は 53\%が着用していた T シャツから回収されたこと から，(4)衣服への移行が殺菌剂の大きな減少要因であるこ とが示唆された（Fig.-9）。

な扔，本スキームは検体塗布 6 時間後に打ける各部位か

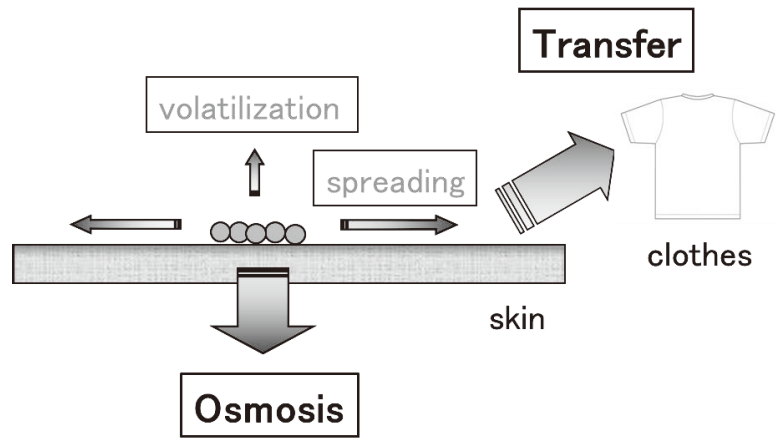

Fig.-9 Schematic illustration for influence of decrease factors of antimicrobial agents derived from the recovery rates at $6 \mathrm{~h}$ after sample application.

らの回収量により導かれたものであり，体表に拡散した殺 菌剂は時間の経過とともに移行や浸透すると予想されるた め, 検体の塗布時間を短くした場合には, 拡散性の寄与度 は上昇すると考えられる。

次に，殺菌剂の残存性に及ぼす発汗の影響を評価した結 果, 通常時よりも発汗時に扔いて, 有意に残存率が低下し た。これは，発汗によって殺菌剤の肌上での拡散や衣服へ の移行が促進されたためと考えられる。

\subsection{IPMP とトリクロサンの比較}

IPMP とトリクロサンの腋窩上での経時残存性の比較に おいて，トリクロサンはIPMPよりも残存しやすいことが 示唆された（3.1）。この理由として，トリクロサンの Log $P$ 值（4.86）は IPMP（3.37）に比べて高い，すなわち疎水 性が高い（水への移行性が低い）ため，汗の分泌を介した 衣服への移行などの影響を受けにくいと考えられる。ま た，トリクロサンの分子量 $(M w=289.5)$ は IPMP $(M w=$ 150.2）よりも大きく, $\log P$ も皮虐内部への浸透に適した $\log P(2 \sim 3)^{7)}$ から乘離しているため, 肌内部に浸透しに くいと考えられ，実際に浸透性はIPMP のほうが高いこと が確認されている（3.2.2）。以上のことから，皮膚表面に 残存することが望まれる殺菌剂の理想的な物性としては, 汗などの分泌による拡散・移行が起こりにくいように疎水 性が高く，皮膚内部への浸透が起こりにくいように分子量

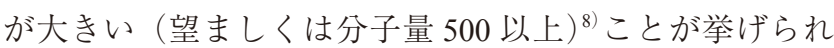
る。

\section{3. デオドラントキーパーの探索について}

4.2 で残存性が高い殺菌剤の要件は見出されたが, 医薬 部外品の有効成分として使用可能な殺菌剤は限られてい る。そのため, 添加成分により IPMP の残存性を高めるこ とが可能かを検証するため，IPMP 減少の主要因である汗 などの分泌物を介した流れ落ちをイメージした in vitro 評 価法を作成した。本評価法を用い，肌への残存性が高いと 
予測された鎖長や構造の異なる 11 種類のオイルエステル について効果性の検証を行った結果, 検証を行ったすべて のオイルエステルで IPMP 残存性の上昇効果が認められ た。オイルエステルの構造と残存率の上昇効果の解析とし て，炭素鎖長違いの構造である IM とIP 抢よびEP と $\mathrm{ES}$, エチルヘキサン酸の結合数が主な違いである $\mathrm{GE}$ と PEの比較に扔いて, 分子量拈よび $\log P$ が大きいほど IPMP 残存量の上昇効果が高いことが示唆された。次に, 分子量㧍よび $\log P$ 以外にも IPMP の残存性に影響を与え る要因を抽出するため, 重回帰分析により IPMP 残存量の 上昇率の予測式を求めた結果, オイルエステルの分子量お よび $\log P$ が大きく，また，有機性值が小さく無機性值は 大きい, すなわち無極性の構造よりも，分極している構造 のほうがIPMP を残存させる効果が高いことが示唆され た。この理由としては, IPMPがフェノール性水酸基を有 しているため, 水素結合などの双極子相互作用によりオイ ルエステルとIPMP との親和性が高まるためと考えられ る。また, 最も $\log P$ の高い OMの効果が低い理由は, 分子量に比較して分極部位が最も少ないため, IPMP と双 極子相互作用を起こしにくく，比較的弱い結合であるファ ンデルワールスカが主となることで，殺菌剤との親和性が 低くなるためと考えられる。

以上のことから, IPMP の残存性を高めるデオドラント キーパーとしては，そのもの自身の耐水性が高い必要があ るため $\log P$ が大きく, 皮膚内部への浸透を抑えるため分 子量が大きいことが必要である。さらにIPMP との親和性 が高い, すなわち, 水素結合等の双極子相互作用を起こし やすい構造であることが，残存性の向上に有利に働くこと が見出された。

\section{5. 結論}

デオドラント剤使用後の腋窩上での殺菌剂の経時残存性 を評価した結果, 殺菌剤の大幅な減少が確認され，このこ とがデオドラント剤の防臭効果が経時的に減少する要因で あると考えられた。この殺菌剤の減少の要因を解析した結
果，衣服への移行と皮膚内部への浸透が主要因と考えられ た。また，IPMPに比べてトリクロサンの残存性が高いの は，分子量が大きく, $\log P$ が高いためと考えられた。さ らに, IPMP の残存性を高める添加成分を検証した結果, 残存性を高めるための要件としては，添加成分自身の耐水 性が高い必要があるため $\log P$ が大きく，皮虐内部への浸 透を抑えるため分子量が大きいことが必要であると考えら れた。また，殺菌剂を肌上に留めるためには親和性が高い ことも必要であり，今回評価したIPMP に対するデオドラ ントキーパーとしては，IPMP と双極子相互作用を起こし やすい構造であることが，残存性の向上に有利に働くこと が見出された。

本試験では殺菌剂を評価対象とし，経時的な挙動の変化 を捉えることで効果性の向上に繋げたが，殺菌剤に限ら ず，効能効果を期待して配合する機能性成分については, その構造・物性・挙動を把握し, 効果を発揮させたい部位 への移行性や残存性に注目して評価することで, 機能性成 分の効果を最大限に発揮できる剤型や処方が見出せ，現状 よりも持続性・効果性の高い製剤の開発に繋がると考える。

\section{引用文献}

1) J. J. Leyden, K. J. Mcginley, E. Holzle, J. N. Labows, A. M. Kligman, J. Invest. Dermatol., 77, 413-416 (1981)

2) D. Taylor, A. Daulby, S. Grimshaw, G. James, J. Mercer, S. Vaziri, J. Cosmet. Sci., 25, 137-145 (2003)

3）ジョン・ J ・ カバラ編, 香粧品医薬品防腐殺菌剤の科 学，フレグランスジャーナル社，1990, p. 501-565

4) P. M. Baxter, J. V. Reed, Int. J. Cosmet. Sci., 5, 85-95 (1983)

5）柳井久江，4Steps エクセル統計（第 3 版），オーエム 工又出版, 2011, p. 210-216

6）甲田善生，本間善夫，佐藤四郎，新版 有機概念図 基礎と応用，三共出版，2008，p. 1-36

7) I. H. Blank, R. J. Scheuplein, D. J. Macfarlance, J. Invest. Dermatol., 49, 582-589 (1967)

8) J. D. Bos, M. M. Meinardi, Exp. Dermatol., 9, 165-169 (2000) 